\title{
Financialization and value: why labour and the labour process still matter
}

Jean Cushen, National University of Ireland, Maynooth

Paul Thompson, University of Stirling and Queensland University of Technology

Forthcoming in Work, Employment and Society

\begin{abstract}
Despite expanding literatures on financialization, scholarship exploring the relationship to labour and the labour process remains under-developed. A further obstacle has arisen from arguments that novel financialized modes of value extraction render the labour process and labour process analysis less relevant. This article challenges that view and explores how the labour process is still a vital focal point for value creation and extraction. It sets out what scholars should 'look for' to understand the ways in which distinctively financialized mechanisms operate in non-financial corporations and how these dynamics are translated into outcomes for and through labour. The article then provides four key propositions, drawing on labour process theory, which specify how those mechanisms are operationalized and their consequences.
\end{abstract}

\section{Introduction}

As the influence of financialization extends, so a number of diverse literatures have emerged which increasingly converge on the message that financialization is a distinct form of capitalism which elevates financial markets, financial actors and financial motives (Epstein, 2005 p.3; Lapavitsas, 2011). A review of scholarship on financialization identifies three thematic strands - as a regime of accumulation; of the modern corporation and of everyday life (Van der Zwan, 2014).

Of these strands, by far the most attention has been paid to financialization as an accumulation regime. Though these discussions appear to move from macro to micro, the focus on labour, work and employment is limited. Where labour is brought into the picture, the emphasis is on indirect outcomes and inferences rather than a systematic examination of how the labour process is implicated in value creation and extraction under financialization'. Recent contributions from Appelbaum and Batt (2014) and Appelbaum, Batt and Clark (2013) argue that financialization necessitates a move away from 
exploring value extraction within the labour process. This, they claim, is because financialized value is extracted primarily outside of the labour process. As Appelbaum and Batt (1994) previously argued the importance of mutual gains from high performance work systems, this is a significant shift. However their focus, and indeed of much of the literature on financialization and labour, is on private equity (PE) and new investment funds (NIFs) rather than the much broader issue of financialization in non-financial corporations (NFCs).

Where explicit attention has been paid to financialization in the workplace, gaps remain. Perhaps the most notable contribution has been the debate around Thompson's disconnected capitalism thesis (DCT) (Thompson, 2003, 2013; Clark, 2009). Thompson links the pursuit of shareholder value, the behaviour of firm management and negative impacts on high performance workplace productivity bargains. However, there is an acknowledged failure to specify and explore the mechanisms through which these trends take place. Scholarship has yet to uncover the novel and distinctively financialized activities taking place within organisations that both affect and are affected by labour. In other words 'what' is happening is increasingly apparent but the 'how' is less clear. Uncovering such mechanisms requires close explorations of the dynamics of value extraction and creation in the labour process at firm and value chain level. This article identifies such mechanisms and in doing so offers a corrective to the influential argument by Appelbaum et al and the wider emergent assumption in the literature, that the labour process is marginalised within financialization. The article proceeds by retracing these steps. It examines the analyses of financialized regimes of accumulation and articulations of links to labour. Secondly it discusses the contributions of the DCT and research on NIFs, setting out the gaps and limits to our knowledge of financialization-labour dynamics. It then seeks to defend and extend the scope of labour process analysis (LPA) by outlining how key transmission and control mechanisms of financialization unfold in NFCs, arguing that novel accounting techniques play a key role. A set of propositions are then developed outlining the impact of and implications for labour.

\section{Finance-dominated regimes of accumulation}

There is now a significant body of work from 'accumulation scholars' ranging from heterodox economists to Marxists (van der Zwan, 2014), concerned with how financialization reflects and shapes the pattern and pace of accumulation and the competing claims of agents within industrial and financial circuits of capital (Demirović and Sablowski, 2013; Lapavitsas, 2001; Lazonick and Mazzucato, 2013; Krippner, 2005; Milburg, 2008; Müller, 2013; Stockhammer, 2008). Though interest in the links between finance and capitalism dates back to Hilferding (1981), contemporary commentators focus on the 
growing share of financial assets and profits of financial corporations relative to GDP, emphasising the point that NFCs in the 'real economy' are fully-engaged actors in financial markets. Use of the term regime does not imply a coherent, stable growth trajectory. The studies listed above all explore the destabilising impact of financialization on growth, additional vulnerability to crises and skewed distributional outcomesii. Additionally, financialization imposes a value logic that disrupts institutional and product market configurations identified traditionally by comparative political economy literatures.

This has led to some justified criticism of over-determinism with respect to contingency and diversity arising from differential exposure to capital markets and incentives for financial agents in national economies (Engelen and Konings, 2010), as well as varied outcomes from the interventions of financial agents such as private equity (Wood and Wright 2012). Our concern is somewhat different. To the extent that literatures on finance-dominant regimes have relevance to this article, it is when the focus goes beyond the macro economy to the firm and inter-firm level. Pressures to meet capital market requirements and/or service debt predispose NFCs to focus on financially leveraged outcomes and balance sheet capitalization over operational measures and outcomes. The resource-reward nexus becomes distorted as the corporate elite position themselves to extract a disproportionate amount of value in relation to the creation process (Lazonick and Mazzucato, 2013). 'Profit financialization' focuses on leveraging value through financial extractions and assets compared to the rate of return on manufacturing and operational investment (Müller, 2013, 9; Milburg, 2008, p. 423). This exacerbates the existing trend of declining proportions of investment as a percentage of operating surplus and has implications for labour with respect to skill development and other aspects of human capital development (Demirović and Sablowski, 2013; Lazonick and Mazzucato 2013). However, aside from inferred effects, plus general talk of transfer of risk to labour, explanatory links at meso and micro level remain weak or indirect. In particular, how and in what ways the labour process remains a source of value are largely unexplored.

\section{The role of labouriii and the labour process}

The DCT brings to the fore the sometimes lost LPA links between workplace change and capitalist political economy and claims that financialization shifts the interconnections and pattern of dominance between industrial, financial and commercial circuits of capital. Financialization becomes a key driver of corporate and workplace change leading to undermining of the stable conditions necessary for workplace-based productivity bargains and investment in human capital. This involves a triple disconnect: between employer objectives in the work and employment spheres; between managerial 
levels and layers within firm governance; between corporate dynamics and state regulation in national business systems.

This theme of disconnections is pursued in recent contributions from Appelbaum, Batt and Clark (2013) and Appelbaum and Batt (2014), though they prefer 'breaches of trust' by PE to workers and other stakeholders. They offer an incisive analysis of how the financialized business model of PE makes money through extracting value from other stakeholders including customers, creditors, suppliers and employees. Their illustrative cases provide evidence of negative labour impacts on jobs, pensions, wages and work intensity. However this leads them to assume the marginalisation of the labour process in value creation and they call for a diverging analytical frame. They argue that scholarship can 'contribute to a more fine-grained theory of value-extraction by moving beyond the labour process and an exclusive focus on labour-management relations to reveal the variety of sources of value extraction under new forms of capitalist governance... the organization of work and labour relations is a limited frame' (2013, p500). Later they extend the argument asserting the need to 'move beyond labour process analysis' (our emphasis) and towards 'institutional analysis of PE mechanisms of value redistribution' (p. 513).

There are three areas of contention here. First, does moving 'beyond the labour process' allow for exploration of value extraction through labour, as well as impacts on workers? Second, by referring to 'an exclusive focus on management-labour relations' the authors mis-characterise the scope of LPA. Third, NIFs are part of, but not the main story of financialization. In the recent period 11 percent of total assets under management worldwide are held by private equity, hedge funds and sovereign wealth funds (Gospel and Pendleton, 2014:3). Appelbaum and Batt are rightly keen to emphasise the distinctive characteristics and effects of PE, focusing on the ways in which higher levels of debt used to buy out companies lead to enhanced pressures for higher than average returns in a short time frame; as well as to the complete dominance of PE partners in firm governance. Despite careful noting of these differences to NFCs, Appelbaum and Batt's general theoretical conclusions are premised on the view that PE 'exemplifies' financialization. (2014, p6). However, the dynamics pertinent to value extraction and the labour process may be at least partially different in NFCs.

This critical interrogation of the Appelbaum, Batt and Clark argument is not in itself adequate. As indicated earlier, largely lacking are studies exploring how distinctive financialized activities are connected to or manifested in NFCs, and more specifically how shareholder value pressures are 'translated' into workplace outcomes and experiences. In another recent contribution exploring the labour outcomes associated with PE and other NIFs, Gospel and Pendleton (2014) refer to 'transmission 
mechanisms' as shortened time horizons, new corporate strategies and shifts in the balance of stakeholder governance, though noting that 'downstream' activities are largely indirect and not easily traceable. The latter is indeed true, but what is needed are accounts that can at least proceed towards that goal. A useful framework is offered by Baud and Durand (2012, p243-4) in their study of financialization and retail firms. Baud and Durand distinguish between the (mainly macro) financialization of objectives (value norms/strategy, investment) and the firm level financialization of operations, including relations with workers, customers and suppliers. Clark and Macey (2015) also draw on these categories to identify the 'contagion effects' of financialization within firms, though they combine them with the idea of 'profit' and 'control' financialization. The former was discussed earlier, while the latter is said to identify managerial strategies that are applied in the workplace.

These categories are helpful in indicating where to look, but the next section sets out what scholars should look for to more fully understand the mechanisms driving financialized outcomes ${ }^{\text {iv }}$.

\section{Financialized investment and valuation in NFCs}

Distinctively financialized pressures enter NFCs via institutional investors who have grown in prominence to own over 80percent of UK equities (Roberts et al., 2006, p. 278) and 73 percent of US equities in 2009 (Tonello and Rabinov 2010). The principal activity of institutional investors appears to consist not merely of holding NFC shares, but buying and selling them based on perceptions of intrinsic value to outperform the index or asset class they are benchmarked against (Blake and Tillerman, 2001; Hendry et al., 2006, p.1103). High investor turnover means corporate management must continuously stimulate a market for their shares by making them desirable both to existing and potential investors (Hendry et al., 2006; Roberts et al., 2006). Corporate chief executives and finance directors now commit more of their time to investor communications (Pye, 2001).

In addition to the changing composition of financial markets, recent decades have seen a shift in investor strategies. The idea that stock has an intrinsic value distinct from the listed price, calculated by estimating future performance took hold and achieved widespread legitimation when economic theory labelled market listings 'informationally deficient' (Grossman and Stiglitz, 1980). Investor acceptance of the paradox positioned estimations of future firm performance as key sources of competitive advantage among the investment community. To estimate intrinsic value, investors, usually via financial analysts, combine company information with a predictive valuation model. A key output of an analyst's report is 'target price' which is their expectation of a company's share price in twelve months. Financial analysts 
play a central intermediary role in capital markets in interpreting and disseminating corporate financial and related market information and their investment recommendations have a material impact on trading activity (Womack, 1996). Institutional investors report using an average of nine different valuation factors to gauge intrinsic stock value (Merrill Lynch Institutional Factor Survey, 2006). The most popular valuation factors are listed in Table One and trends in recent years indicate that investors are placing heightened emphasis on cash returns (Bank of America Merrill Lynch Institutional Factor Survey, 2012).

Table One: Top Valuation Factors used by Institutional Investors

\begin{tabular}{|l|l|}
\hline Factor & $\begin{array}{l}\text { Percent } \\
\text { Using }\end{array}$ \\
\hline Price Earnings (P/E) Ratio & 81 \\
\hline Beta & 68 \\
\hline Enterprise Value (EV)/EBITDA & 60 \\
\hline Return on Earnings (ROE) & 55 \\
\hline Size & 54 \\
\hline Price/Free Cash Flow (P/FCF) & 53 \\
\hline Price to Book (P/B) Ratio & 53 \\
\hline Share Repurchase & 51 \\
\hline Estimate Revision & 50 \\
\hline Profit Margins & 47 \\
\hline
\end{tabular}

Source: Bank of America Merrill Lynch Institutional Factor Survey 2012

The prominence of these factors mean it is important to consider how they shape value related decision making within NFCs. Creating investor confidence in an equity's intrinsic value requires management to craft corporate strategies that enhance the organisation's performance under the numerous financialized valuation factors. A concern shared among a diverse range of academic and professional commentators is the tendency of the dominant valuation factors to steer corporate management away from internal firm investment and value creating activities (Orhangazi, 2008). In particular, popular financial factors tend to produce ratios not values, comprising of a numerator and denominator which are an indication of profits and costs respectively. Firm management have generally sought to improve their ratio by reducing the denominator through cost reduction, because value extraction activities are more predictable and generally accessible within a short timeframe. Increasing the growth side of the ratio is riskier as value creation gains are less certain and only likely to appear five to ten years later (Christensen and van Bever, 2014, p. 4). In fact, financial actors tend not to respond positively to 
complex exploratory innovation (Gupta, 2012) and favour value creation strategies only among firms deemed to be high performing (Jacobs and Singhal, 2014). The pressure on management to reduce costs is compounded by the historic long-term decline in the ability of firms in many sectors to create value through raising price. Prominent innovation strategists lament this trend towards the 'wrong' kind of innovation namely 'efficiency innovation' which eliminates jobs rather than 'market-creating innovation' that creates them (Christensen and van Bever, 2014).

All these processes drive financialization of NFC investment which takes two main forms. First, an investor-oriented redistributive agenda through dividend payments and share buybacks (Van der Zwan, 2014, p.108). Second, the growth of investment in financial assets and activities rather than those at an 'operational' level, often to the detriment of the productive capacity of firms. The move away from value creating investment is increasingly apparent in sectors where product market returns are longer term and less predictable. In 'Big Pharma' the high R\&D spend required for exploratory innovation and the difficulty in quantifying future product market returns has seen trends towards outsourcing of R\&D activities to bio technology firms (Andersson at al, 2010). Financialized investment also helps to explain trends within certain business models. Baud and Durand (2012) show that the financial assets ratio of leading retail firms in the 2000s increased for most, accounting for an upward trend in return on equity despite constraints on domestic sales growth and international expansion. Milburg also notes evidence indicating 'a change in the gap between the rate of return on manufacturing investment and the rate of return on financial assets' (2009: 423). Ultimately, the novel financialized valuation factors are key transmission mechanisms connecting NFCs with the interests of investors. Achieving these financialized targets has led to distinct forms of organisational control or 'control financialization'.

NFCs rely heavily on accounting techniques that provide quasi-legal firm level control mechanisms to position financial targets central and dominant in decision making (Froud et al., 2006; O'Neill, 2001). Budgeting processes can provide a firm wide control mechanism through which targets relating to value creation and extraction can be disseminated and measured (Cushen, 2013). Accounting regulations require that internal company investment and projects be assessed and justified on the basis of measures such as Net Present Value, Internal Rate of Return (IRR), payback period, discounted payback period, average accounting rate of return and profitability index. Management can select the financial measure(s) that most closely mirror the calculations of the valuation factor(s) they wish to perform well 
against, allowing them to orient and assess lower organisational levels to the financialized targets. However arriving at the desired financial endgame is neither straightforward nor automatic.

\section{Labour process issues and impacts}

Financial targets must be delivered by employees - meaning it is within the labour process that interventions prompted by the speculative financialized firm valuations confront a 'moment of truth'. In the discussion below are four interrelated propositions consistent with LPA that link the aforementioned transmission and control mechanisms with financialized labour outcomes.

Proposition one: Financialization drives forms of value extraction based on squeezing labour costs and revenues.

The pursuit of shareholder value, expressed by financial valuation factors, prompts 'dramatic efforts to control costs' (Milburg 2009: p.428) as 'market pressure to maintain asset prices is, at the same time, a pressure on labour as variable capital' (Bryan et al., 2009: p.467). Value extraction via cost cutting is associated with labour and the labour process through headcount reduction interventions such as redundancies, outsourcing, centralisation and supply chain harmonisation, as well as increasing reward insecurity. Headcount reduction is central to financialized 'downsize and redistribute' strategies (Lazonick and O'Sullivan, 2000) and share buybacks (Lazonick, 2012). Furthermore, accounting techniques are important mechanisms used to identify and communicate labour cost reduction initiatives. In NFCs, employee related expenditure is categorised in financial accounts as a cost, namely operational expenditure (OPEX). OPEX reduction is a key measure for signalling commitment to and delivery of targets to shareholders. Financial markets react positively to announcements relating to OPEX reduction, particularly redundancies and outsourcing (Farber and Hallock, 1999). Recent decades have seen increased use of cost accounting techniques such as activity based costing ( $A B C$ ) and benchmarking due primarily to the restructuring and cost cutting opportunities that $A B C$ prompts. The shares of firms adopting $A B C$ outperform matched non-ABC firms in the short term by approximately 27 percent (Kennedy and Affleck-Graves, 2001).

Additionally, financialization affects wage levels and dispersion given that 'as the circuits of capital change...[there is an] emphasis to drive down the labour share' (Clark and Macey, 2015, p.26). Though rapidly growing wage inequality within firms is a longer term macro-economic phenomenon, increased emphasis on profit targets and reducing payroll sharpens that divide. Cost reduction targets exert 
downward pressure on wages and constraints on the ability to share performance improvements with the workforce (Cushen, 2013). This is confirmed in Appelbaum and Batt's illustrative cases, 'In the PEowned plants post buyout, higher productivity was accompanied by lower employment growth and wage reductions, thereby contributing to an increase in the productivity-wage gap' $(2014,233)$. In some instances financial engineering and squeezing labour might not be coterminous processes, such as when staffing costs had been cut back in UK privatised utilities to the extent that debt leverage was a more viable source of value reallocation (Goergen et al 2014). However,. Such practices are still likely to weaken the position of and constrain future internal investments in labour, thereby indirectly recoupling the processes.

Proposition two: Financialized investment is a driver of perpetual restructuring that exacerbates work insecurity and intensification.

Interventions designed to ward off investor risk and ensure investor returns, such as moving to high dividend ratios, share buybacks and taking on debt, create a bias towards investment that is geared more towards financial engineering. This, in turn, feeds corporate restructuring which has surged in recent decades in order to create a vision of a better future for investors. It arises primarily from the desire to deliver value through the disposal and acquiring of corporate assets based on their status within accounting techniques. For example it is not uncommon for firms to outsource teams of personnel, a cost, but retain ownership of the equipment, an asset employees continue to use when outsourced. Within this uncertainty labour absorbs risk disproportionate to the reward they may derive. The perpetual restructuring and continuous organisational upheaval affect labour and the labour process in two key ways. Firstly, employees experience heightened employment insecurity due to the emphasis on headcount reduction (Chan, 2013; Kalleberg, 2011, Lazonick, 2012) as well as role insecurity, as their position and status within the organisation is in perpetual flux (Cushen, 2013). Secondly, depleting internal operational investment and continuous structural upheaval trigger work intensification linked to reduced headcount, use of peripheral employment, less development and training and the need to navigate continuously restructured work processes and changing personnel. Value gains from reorganisation of work and restructuring of employment in firms and across supply chains are appropriated by shareholders (Baud and Durand 2012: p.256). Combining elements of propositions two and three, Clark and Macey's (2015, pp. 19-20) study shows how pressures to service debt and dividend payments following a PE takeover of the Automobile Association in 2013 led to 3400 employees being 'managed out of the business' with work intensification for those remaining. 
Proposition three: Financialization engenders a shift in control mechanisms that strengthens punitive performance regimes.

Financialized valuations create a 'performance exposure' (Bryan et al., 2009, p.466) that drives management by numbers and strengthens the trend towards centrally driven, short term financial measures of performance. Firm valuations prompt a myriad of, often concurrent, workplace initiatives that come with defined financial targets that management hope will be accepted and delivered by labour at the point of production. The worst thing investors can be told is that an organization did not achieve targets and a failure to deliver the numbers with one initiative prompts more interventions in order to find alternative routes to the promised future. The consequences for labour relate primarily to the increased use of numerics in performance management as corporate profit targets are cascaded downwards (Ezzamel et al, 2008). Localised versions of these financial measures are disseminated throughout the organisation and used to measure progress against both value creation and extraction targets, aided in many cases by electronic monitoring and tighter work flow (Taylor 2013). The shift towards cascaded financial controls, together with the associated insecurity and transfer of risk to labour either marginalises cultural and commitment-led interventions or diminishes their potential effectiveness (Cushen and Thompson, 2012). This is not to say that normative controls are irrelevant in managerial regimes, but that high performance and commitment-seeking are frequently recast as conduct and behavioural descriptors manifested in performance demonstrated by achievement of financial targets (Taylor 2013, p. 46-7). New configurations of control also recast labour responses. Employees across a range of skill levels and disciplines are increasingly required to consider and quantify their contribution to the 'bottom line' (Ezzamel et al., 2008; Gleadle and Cornelius, 2008).

\section{Proposition four: Financialization reinforces market discipline and market attitudes}

Tighter internal controls, post-crash fiscal constraints and other external circumstances favourable to capital, combined with longer term weakening of collective labour organisation has resulted in market discipline limiting the scope for resistance. A range of OECD statistics and qualitative studies show how capital has reasserted its power over organised labour and labour markets in the US, UK and Western Europe (Peters, 2011). However, labour's response is not limited to mere compliance. Enhanced instrumentalization of labour effects employees' behaviours and perceptions of the employment experience. Business sources from HR professionals (Chartered Institute of Personnel and Development 2007) and The Harvard Business Review (Caulkin 2014) join academics in charting declining trust and employee engagement levels, rising cynicism and a more general crisis of attachment and disaffection 
for companies (Naus et al, 2007; McCann 2013). Financialization is part of and adds to these trends, prompting cynical and calculative behaviours in circumstances where employees understand themselves as a quantifiable, disposable commodity and as a distinct stakeholder with interests that conflict with and lose out to those of capital.

\section{Concluding remarks}

Far from being marginalized by financialization, this article demonstrates that the manner in which labour and the labour process is being called upon to contribute to organisational value has in fact expanded. Appelbaum, Batt and Clark (2013) have called for a more fine grained account of value extraction that looks beyond the labour process and labour process analysis. While in no way dissenting from the view that financialization broadens the dynamics of value creation and extraction at macro and micro level, there remains a key challenge in reverse terms - to connect the two phenomena. An important part of making such connections is to identify 'transmission' mechanisms that go beyond general reference to short time horizons or new corporate strategies. A distinctive contribution of this article is that it identifies meso level mechanisms, in particular valuation factors and accounting practices that act to coordinate an assembly of firm level elements, namely people and processes, orienting them toward achievement of financial targets. The outcomes manifested in the labour process, such as headcount reduction, work restructuring and cascading financial controls, operate both as key subjective features of corporate narratives and objective measures of 'progress' towards meeting capital market expectations. This is consistent with the previously-discussed concepts of profit and control financialization (Clark and Macey 2015), with meso-level mechanisms operating as means of embedding broader financialized objectives through operational strategies and measures.

It is important, however, to recognise that financialization within the corporate sphere is not a single, coherent process. Nor is it defined by the complete supplanting of value expansion through production. Rather it is characterised by tensions between sources of value extraction and the inability of firms to achieve targets in the manner speculated or, in some cases, at all (Burnham, 2010; Froud et al., 2006). For labour, many of the propositions outlined in the previous sections are, 'interacting with accelerating and exacerbating longer term trends such as labour market insecurity, externalization and internationalisation' (Thompson, 2013). Labour process change therefore continues to reflect product and labour market competition and sources of value. This is a shift in the circuits of capital not a wholesale displacement and the extent to which financialization is a primary or secondary driver of change varies by industry. 
Finally, while conditions of value extraction have created a need to move beyond workplace-centric employment relations and national varieties of capitalism, LPA is well placed to make connections between accumulation regimes and firm and industry-level dynamics. Continuing to focus on labour and the labour process is an important corrective to the claims that changes in value creation and extraction in financialization and other spheres are focused wholly or mainly outside production. This is clearly not the end of the story. A priority for future research is company, industry or value chain framing in which financialization trajectories and the relations with labour can be more adequately traced and explained. Aggregate level data on the general characteristics and effects of financialization is very useful for understanding and critiquing the new business models. However, as Appelbaum and Batt (2014) accept, there are limits to this data in assessing labour issues such as job destruction and creation hence their own detailed company cases. With a clearer identification of mechanisms and their effects at strategic and operational levels, this article has been a contribution towards the development of frameworks for undertaking such investigation.

\section{REFERENCES}

Andersson T, Gleadle P, Haslam C and Tsitsianis N (2010) Bio-pharma: A financialized business model. Critical Perspectives on Accounting 21(7): 631-641.

Appelbaum E and Batt R (1994). The new American workplace: Transforming work systems in the United States. Cornell University Press.

Appelbaum E, Batt R and Clark I (2013) Implications of financial capitalism for employment relations research: evidence from breach of trust and implicit contracts in private equity buyouts. British Journal of Industrial Relations 51(3): 498-518.

Appelbaum, E, Batt, R (2014) Private Equity at Work: When Wall Street Manages Main Street. Russell Sage Foundation

Bank of America Merrill Lynch (2012) Annual Institutional Factor Survey \#21. Report.

Baud C, Durand C (2012) Financialization, Globalization and the Making of Profits by Leading retailers. Socio-Economic Review 10(2): 241-266.

Blake D, Tillerman A (2001) Performance Benchmarks for Institutional Investors: Measuring, Monitoring and Modifying Investment Behaviour. The Pensions Institute Discussion Paper PI-0106 
Bryan D, Martin R and Rafferty M (2009) Financialization and Marx: Giving labor and capital a financial makeover. Review of Radical Political Economics 41(4): 458-472.

Burnham P (2010) Class, capital and crisis: a return to fundamentals. Political Studies Review 8(1):27-39.

Caulkin, S (2014) Liberating Incentives. Financial Times Business Education, September.

Chan S (2013) 'I am King': Financialization and the paradox of precarious work. The Economic and Labour Relations Review 24(3): 362-379.

Christensen CM, van Bever D (2014) The capitalist's dilemma. Harvard Business Review 92(6): 60-68.

Clark I (2009) Owners and managers disconnecting managerial capitalism? Understanding the privateequity business model. Work, Employment \& Society 23(4): 775-786.

Clark I, Macey R (2015) How is financialization contagious? What role for HR practices play in the capture of workplace outcomes in financialized firms? Paper to 33rd International Labour Process Conference, April Athens 13-15 April.

Cushen J (2013) Financialization in the workplace: Hegemonic narratives, performative interventions and the angry knowledge worker. Accounting, Organizations and Society. 38(4): 314-331.

Cushen J, Thompson, P (2012) Doing the right thing? HRM and the angry knowledge worker. New Technology, Work and Employment. 27(2): 79-92.

Davis GF, Marquis C (2005) Prospects for organization theory in the early twenty-first century: Institutional fields and mechanisms. Organization Science. 16(4):332-343.Demirovic A, Sablowski T (2013) The finance-dominated regime of accumulation and the crisis in Europe, Analysen, Rosa Luxemburg-Stiftung: Berlin. Accessed 23 July 2014.

Engelen E, Konings, M (2010) Financial capitalism resurgent: Comparative institutionalism and the challenges of financialization. In: Morgan G, Campbell J, Crouch C, Pedersen O K and Whitley R. (Eds.) The Oxford handbook of comparative institutional analysis, 601-624.

Epstein GA (2005) Introduction. In: Epstein GA (ed.) Financialization and the world economy. Cheltenham, Northampton, MA: Edward Elgar, 3-16. 
Ezzamel M, Wilmott $\mathrm{H}$ and Worthington $\mathrm{F}$ (2008) Manufacturing shareholder value: The role of accounting in organizational transformation. Accounting, Organizations and Society 33(2): 107-140.

Farber H, Hallock KF (1999) Changing stock market response to announcements of job loss: Evidence from 1970-1997. Industrial Relations Working Paper No. 793. New Jersey: Princeton University.

Froud J, Johal S, Leaver and Williams K (2006) Financialization and strategy: narrative and numbers. London: Routledge.

Gleadle P, Cornelius N (2008) A case study of financialization and EVA. Critical Perspectives on Accounting 19(8): 1219-1238.

Goergen M, O'Sullivan N and Wood G (2014) The consequences of private equity acquisitions for employees: new evidence on the impact on wages, employment and productivity. Human Resource Management Journal 24(2):145-158.

Gospel H, Pendleton A and Vitols S (eds.) (2014) Financialization, New Investment Funds, and Labour: An International Comparison. Oxford University Press.

Grossman SJ, Stiglitz J(1980) On the Impossibility of Informationally Efficient Markets. American Economic Review 70(3): 393-408.

Gupta A (2012) What the Market Likes: External Learning and Firm Valuation. http://www.camden.rutgers.edu/pdf/FacultyResearch/Gupta.pdf

Hendry J, Sanderson P, Barker R and Roberts J (2006) Owners or traders? Conceptualizations of institutional investors and their relationship with corproate managers Human Relations 59(8): 11011131.

Hilferding R. (1981) Finance Capital A Study of the Latest Phase of caoitalist Development, London: Routeldge and Kegan Paul.

Jacobs BW, Singhal VR (2014) The effect of product development restructuring on shareholder value Production and Operations Management 23(5): 728-743.

Kalleberg AL (2011) Good jobs, bad jobs: The rise of polarized and precarious employment systems in the United States, 1970s-2000s. Russell Sage Foundation. 
Kennedy T, Affleck-Graves J (2001) The impact of activity-based costing techniques on firm performance. Journal of management accounting research 13(1): 19-45.

Krippner GR (2005) The financialization of the American economy. Socio-Economic Review 3(2), 173208.

Lapavitsas C (2011) Theorizing financialization. Work, Employment \& Society 25(4): 611-626.

Lazonick W, O'Sullivan M (2000) Maximising Shareholder Value: A New Ideology for Corporate Governance. Economy \& Society 29(1): 13-35.

Lazonick W (2012) The Financialization of the US Corporation: What Has Been Lost, and How It Can Be Regained. Seattle University Law Review 36, 857.

Lazonick W, Mazzucato M (2013) The risk-reward nexus in the innovation-inequality relationship: who takes the risks, who gets the rewards? Industrial and Corporate Change 27 (4): 1093-1128.

McCann L (2013) Disconnected amid the networks and chains: Employee detachment from company and union after offshoring. British Journal of Industrial Relations 52(2): 237-260.

Merrill Lynch (2006) Annual Institutional Factor Survey \#15.

Milburg W (2009) Shifting Sources and Uses of Profits: Sustaining US Financialization with Global Value Chains. Economy and Society 37(3): 420-451.

Müller, J (2013) Theses on Financialization and the Ambivalence of Capitalist Growth, Working Paper der DFG-KollegforserInnengruppe Postwachstumsgesellschaften, Frederich-Schiller-Universitätt Jena.

Naus F, van Iterson A and Roe R (2007) Organizational Cynicism: Extending the Exit, Voice, Loyalty and Neglect Model of Employees' Response to Adverse Conditions in the Workplace. Human Relations, 60 (5): 683-718.

O'Neill P (2001) Financial narratives of the modern corporation. Journal of Economic Geography 1(2) 181-199.

Orhangazi Ö (2008) Financialization and capital accumulation in the non-financial corporate sector: A theoretical and empirical investigation on the US economy: 1973-2003. Cambridge Journal of Economics 32(6): 863-886. 
Peters J (2011) The rise of finance and the decline of organised labour in the advanced capitalist countries. New Political Economy 16(1): 73-99.

Pye A (2001) Corporate boards, Investors and their relationships: accounts of accountability and corporate governing in action. Corporate Governance: An International Review 9(3): 186-195.

Roberts J, Sanderson P, Barker R and Hendry J (2006) In the mirror of the market: The disciplinary effects of company/fund manager meetings. Accounting, Organizations and Society 31(3):227-294

Stockhammer E (2008) Some stylized facts about the finance-dominated accumulation regime. Competition and Change 12 (2): 184-201.

Taylor P (2013) Performance Management and the New Workplace Tyranny. A Report for the Scottish Trade Union Congress. Glasgow: University of Strathclyde.

Thompson P (2003) Disconnected capitalism: or why employers can't keep their side of the bargain. Work, employment and society 17(2): 359-378.

Thompson P (2013) Financialization and the workplace: extending and applying the disconnected capitalism thesis. Work, Employment and Society 27(3): 472-488.

Tonello M,Rabimov S (2010) The 2010 Institutional Investment Report: Trends in Asset Allocation and Portfolio Composition. New York: The Conference Board Report Number:R-1468-10-RR

Van der Zwan N (2014) Making sense of financialization. Socio-Economic Review 12(1): 99-129.

Womack K L (1996) Do brokerage analysts' recommendations have investment value?. The Journal of Finance 51(1): 137-167.

Wood G, Wright M (2012) Crisis, Experimentation and Change: The Case of Private Equity and PTPs. Competition \& Change 16(4) 281-302.

\section{Acknowledgements}

The authors would like to thank the organisers - Peter Nolan and lan Clark - of the 'Financialization: What Does it Mean for Work and Employment?' Workshop at the University of Leicester for the opportunity to present a version of this paper and receive valuable feedback. 


\section{Notes}

' Labour is viewed as a central source of value creation and financialization acts in part through value extraction in the labour process. Though a work in progress, this terminology draws on radical accounting frameworks (Lazonick and Mazzucato 2013; Froud J, Johal S, Leaver and Williams K, 2006) rather than the labour theory of value.

ii Confusion in the use of accumulation regime can arise because the term derives in part from regulation theory, some of whose adherents argued that financialization offered a basis for a new stable growth regime (see Wood and Wright 2012). As the detailed treatment in van der Zwan (2014) makes clear that orientation is not shared by contemporary accumulation scholars.

iii A focus on labour is clearly broader than on the labour process. For example, Bryan, Martin and Rafferty (2009) argue that financialization constitutes labour as a form of capital, advancing into the household and private sphere as a 'frontier of accumulation', binding labour to 'participate in expanded reproduction'.

iv A mechanism is '. . . an assembly of elements producing an effect not inherent in any one of them. A mechanism is not so much about 'nuts and bolts' as about 'cogs and wheels'.. .the wheelwork or agency by which an effect is produced' (Hernes 1998, p. 74 in Davis \& Marquis, 2005, p.336).

Jean Cushen is a lecturer within the School of Business at the National University of Ireland, Maynooth, where she teaches in the areas of human resource management and business and society. Jean's research interests relate primarily to labour process theory, human resource management and industrial and economic sociology. Jean has published on these topics in international academic journals and in HRM practitioner publications.

Paul Thompson is Professor of Employment Studies at the University of Strathclyde and Adjunct Professor at the School of Management, Queensland University of Technology. A former co-editor of Work, Employment and Society, he has published eleven books and over 50 refereed journal articles and is the Convener of the International Labour Process Conference Steering Group. 